https://doi.org/10.19195/0137-1150.174.12

Data przesłania artykułu: 17.03 .2020

Data akceptacji artykułu: 10.05.2020

\title{
DANUTA PYTEL-PANDEY
}

Uniwersytet Wrocławski, Polska

(University of Wrocław, Poland)

\section{Agresja językowa wyrażona dyrektywnymi aktami mowy (żądania)}

\section{Linguistic aggression expressed by directive speech acts (requests)}

\section{Abstract}

This article discusses the problem of aggression in contemporary communication. At the beginning, the author answers the question: What is verbal aggression? Then he explains why directive speech acts can be a good tool in the mouth of an aggressor? At the end, the author gives examples of aggressive statements which use directive speech acts (requests).

Keywords: linguistic communication, aggression, directive speech acts, request

\section{Языковая агрессия, выраженная директивными речевыми актами (требования)}

\section{Резюме}

В настоящей статье рассматривается проблема агрессии в современной коммуникации. Представлены дефиниции этого явления, разработанные разными исследователями. Далее объясняется, почему директивные акты речи являются хорошим средством для выражения языковой агрессии. В последней части исследования представлены примеры агрессивных высказываний, в которых были употреблены директивные акты речи - требования.

Ключевые слова: языковая коммуникация, агрессия, директивные акты речи, требование 
Językiem można zmiażdżyć człowieka.

przysłowie chińskie

\section{Wprowadzenie}

Skala agresji we współczesnych kontaktach językowych od pewnego czasu stale rośnie. Zjawisko to nasiliło się w drugim dziesięcioleciu tego wieku i osiągnęło poziom, który dotychczas nie był obserwowany. Taka sytuacja skłania przedstawicieli wielu dziedzin nauki do podejmowania badań przede wszystkim nad przyczynami zaistniałej sytuacji, aczkolwiek nie mniej ważnym zadaniem jest analiza środków językowych, po jakie sięgają agresorzy, aby być skutecznymi w swoich działaniach.

Przedmiotem niniejszej analizy będzie wyrażanie agresji werbalnej w języku polskim za pomocą dyrektywnych aktów mowy — żądań. Materiał językowy pochodzi z drugiego dziesięciolecia obecnego wieku i został zaczerpnięty z wypowiedzi osób/do osób powszechnie znanych w przestrzeni publicznej: polityków przynależących do różnych partii politycznych, dziennikarzy stawiających niewygodne (w mniemaniu współrozmówcy) pytania oraz innych osób ogólnie rozpoznawalnych.

\section{Wybrane współczesne polskojęzyczne badania nad agresją językową}

Zintensyfikowane zainteresowanie badaczy problemem agresji w polskiej komunikacji werbalnej obserwuje się od początku XXI wieku. Zaowocowało ono publikacjami, które zainspirowały szerszą dyskusję nad tym problemem. Należy zwrócić uwagę na kilka z nich. Rozpocznę od książki Henryka Pietrzaka Agresja — konflikt - społeczeństwo (2000). Badacz zajął się w niej przedstawieniem teorii agresji indywidualnej i określeniem zjawiska agresji zbiorowej, a potem wskazał drogę od agresji jednostek ludzkich do konfliktów społecznych — prowadzącą w konsekwencji do powstania agresji zbiorowej.

Następną publikacją ważną dla językoznawczych badań nad agresją jest monografia Marii Peisert Formy i funkcje agresji werbalnej. Próba typologii (2004). Autorka zaprezentowała tu jawne i zakamuflowane formy agresji językowej i ich funkcje. Zwróciła też uwagę na role socjalne i miejsca sprzyjające powstawaniu aktów agresji językowej. Według Peisert szczególnie narażone na pojawienie się zachowań agresywnych są miejsca i sytuacje, w których ludzie wystawieni są na mocne obciążenie psychiczne i fizyczne. Należą do nich według badaczki: rodzi- 
na, szkoła, wojsko, rolnictwo, rzemiosło i handel, górnictwo i przemysł, parlament i polityka, polemiki religijne i duchowieństwo, sport, miejsca pracy, internet i zakłady karne (Peisert, 2004, s. 171-178). Nietrudno zauważyć, że z obserwacji tych wynika, iż zakres miejsc podatnych na powstawanie wypowiedzi agresywnych obejmuje swoim zasięgiem w jakimś stopniu praktycznie całe społeczeństwo. Na końcu badaczka wskazała również, jakie językowe i pozajęzykowe zachowania mogą blokować agresję.

Agresja była też przedmiotem rozważań artykułów zamieszczonych w 17 tomie serii „Język a Kultura”, zatytułowanym Życzliwość i agresja w języku i kulturze, pod redakcją Anny Dąbrowskiej i Alicji Nowakowskiej, opublikowanym w 2005 roku. Na szczególną uwagę z punktu widzenia niniejszej analizy zasługują następujące tytuły: Agresja i życzliwość w kontekście zachowań komunikacyjnych Tomasza Smereki, Co to jest agresja? Studium semantyczne Alicji Witorskiej oraz Przejawy życzliwości i agresji w wypowiedziach publicznych (na przykładzie języka Rady Miejskiej Bydgoszczy) Elżbiety Laskowskiej.

Kolejną ważną pozycją dotyczącą badań nad agresją w języku polskim jest książka Ireny Kamińskiej-Szmaj Agresja językowa w życiu publicznym. Leksykon inwektyw politycznych 1918-2000 (2007). Publikacja ta została podzielona na dwie zasadnicze części. Pierwsza przedstawia najważniejsze zagadnienia związane z komunikacją polityczną — zmieniającą się w ciągu ubiegłego wieku. Autorka mówi o współczesnej komunikacji politycznej, że: „Szermierki słowne, a często brutalna walka na słowa, zostały wpisane w rytuał sprawowania władzy, w którym uczestniczą też mniej lub bardziej podekscytowani słuchacze, czytelnicy, widzowie, bo przecież dla nich te igrzyska są organizowane" (Kamińska-Szmaj, 2007, s. 7). Natomiast drugą część książki Kamińskiej-Szmaj tworzy Leksykon inwektyw politycznych, które pojawiły się w latach 1918-2000.

Ostatnią monografią, o której chcę powiedzieć, jest książka Bożeny Taras Agresja. Studium semantyczno-pragmatyczne (2013). Zawiera ona analizę agresji przez pryzmat badań językoznawczych i nauk pokrewnych, spojrzenie na to zagadnienie z perspektywy semantyki i pragmalingwistyki.

\section{Współczesne definicje agresji werbalnej}

Definicja terminu ,agresja” podawana przez SJP brzmi: „wrogie, zaczepne zachowanie się; też: silne negatywne emocje wywołujące takie zachowanie; / zbrojna napaść jednego państwa na drugie" (www5). Dla badań językoznawczych istotne jest znaczenie pierwsze.

Agresja werbalna w badaniach nad komunikacją nazywana jest także agresją słowną lub agresją językową. W Wikipedii, która w obecnych czasach jest dla wielu osób podstawowym źródłem informacji, znajdujemy następującą definicję agresji językowej: „napastliwe, brutalne zachowanie nadawcy wypowiedzi wobec 
uczestników komunikacji językowej, przeciwne zasadom grzeczności wypowiedzi" (www3).

Henryk Pietrzak określa ją jako:

reakcję słowną, której zadaniem jest zniszczenie lub zranienie ego. Bodźcem szkodliwym są tutaj groźba i odrzucenie. Groźba jest reakcją, która symbolizuje, zastępuje lub bezpośrednio poprzedza atak. Odrzucenie w sensie werbalnym polega na określeniu obiektu agresji jako osoby złej, niepotrzebnej — określenie jej w kategoriach awersyjnych. (Pietrzak, 2000, s. 33)

Z kolei Jan Mazur i Małgorzata Rzeszutko przez agresję językową rozumieją:

ogół zachowań lingwistycznych zmierzających do werbalizacji protestu lub gniewu w stosunku do osób bądź instytucji, ukazania skrajnie negatywnego nastawienia do określonych zjawisk, m.in. poprzez stosowanie wyrazów, wyrażeń bądź zwrotów odczuwanych współcześnie przez użytkowników ogólnej polszczyzny w kontaktach oficjalnych jako niestosowne, prostackie, nieprzyzwoite lub ordynarne. (Mazur, Rzeszutko, 2000, s. 150-151)

Natomiast Maria Peisert pojmuje agresję językową jako

interpersonalne działanie językowe i pozajęzykowe, na które składają się (z punktu widzenia pragmatyki) w przeważającej części ekspresywy, wyrażające negatywny stan uczuciowy nadawcy wobec odbiorcy, aktualizowany w chwili realizacji działania językowego z intencją zdeprecjonowania odbiorcy, poniżenia jego godności itp. (Peisert, 2004, s. 39)

Każda z podanych definicji agresji werbalnej wskazuje, że zjawisko to ma ścisły związek z łamaniem podstawowych norm grzecznościowych obowiązujących w danym społeczeństwie, jest wystąpieniem przeciwko nim w celu zranienia, zniszczenia ego odbiorcy i wskazania tym samym, że nie zasługuje on na respekt i poszanowanie. W odniesieniu do dwóch głównych zasad polskiej etykiety językowej nazwanych przez Małgorzatę Marcjanik (1993, s. 271-281) oznacza to, że w wypowiedzi agresywnej:

1. nadawca nie okazuje szacunku partnerowi dialogu. Odnosi się to zwłaszcza do osób starszych, kobiet, przełożonych, osób pełniących cieszące się społecznym prestiżem funkcje. Jednocześnie nadawca nie umniejsza roli własnej osoby, depcząc tym samym podstawy grzeczności w polskiej etykiecie;

2. nadawca nie przejawia życzliwego zainteresowania sprawami ważnymi dla partnera komunikacji oraz jego najbliższej rodziny, głównie małżonka (zwłaszcza stanem zdrowia, działalnością zawodową, aktualnymi wydarzeniami rodzinnymi i zawodowymi). Okazywane zainteresowanie ma charakter złośliwy, nieszczery, wrogi, ma deprecjonować odbiorcę i jego sprawy, problemy, otoczenie itp.

Na zmiany zachodzące w sposobie komunikacji Polaków wskazywała Antonina Grybosiowa już na początku XXI wieku, gdy pisała: „,echą naszej współczesnej kultury jest walka na słowa, w której chętnie wypowiada się negatywne sądy o innych, miesza się w ich sprawy oraz zadaje osobiste pytania" (Grybosiowa, 2001, s. 9).

W ciągu minionych dwóch dziesięcioleci tendencja ta przybrała jeszcze na sile, szczególnie w odniesieniu do języka mediów i polityki, osiągając niezna- 
ny dotychczas poziom. Arogancki, niegrzeczny, zaczepny styl komunikacji wielu przedstawicieli elit staje się dla słuchaczy chętnie naśladowanym wzorcem i jednocześnie jest odzwierciedleniem modelu zachowania aprobowanego w społeczeństwie lub niektórych jego kręgach.

Z pozycji badań socjolingwistycznych najistotniejsze wydaje się spojrzenie na źródło agresji słownej nasilającej się w ostatnim czasie jako:

— efekt frustracji, będącej wynikiem szybkiego tempa życia, dążenia do sukcesu i ponoszonych porażek na gruncie osobistym i zawodowym;

- skutek negatywnego wpływu współczesnych społeczeństw i układów w nich panujących na poszczególne jednostki;

— konsekwencję braku współczesnych autorytetów i pozytywnych wzorców przy jednoczesnym odrzuceniu, lekceważeniu i niedocenianiu albo upadku wcześniejszych;

- aprobatę, a nawet zachwyt agresją w sztuce, literaturze, filmie, grach komputerowych, codziennym zachowaniu i postępowaniu wobec drugiego człowieka;

- sposób na zwrócenie na siebie uwagi otoczenia, chęć bycia zauważonym jako jednostka silna, niezależna, wolna od więzów etyczno-moralno-kulturowych;

- postępowanie polskich elit politycznych walczących o zachowanie lub zdobycie władzy;

— sposób działania w życiu prywatnym i publicznym w celu podporządkowania sobie innych, świadome manipulowanie wizerunkiem i poglądami otoczenia dla osiągnięcia własnych korzyści (zob. Pytel-Pandey, 2018, s. 138).

Irena Kamińska-Szmaj we wspomnianej już książce Agresja językowa w życiu publicznym. Leksykon inwektyw politycznych 1919-2000 jako źródła agresji językowej w przestrzeni publicznej wskazuje:

— ideologie, w których w założeniach tkwi niechęć (nienawiść) do innych (obcych) i dla których podsycanie wrogości i nienawiści rasowych, narodowych, klasowych, grupowych staje się podstawą do formułowania systemów wartości usprawiedliwiających wrogość do innych;

— ideologie wyrosłe na gruncie przemian rewolucyjnych, niszczące fizycznie i słowem tych, od których gwałtem przejęto władzę, zmierzające do dehumanizacji swoich ofiar, aby w ten sposób uzasadnić przemoc i bezprawie;

— przejęcie przez polityków strategii komunikacyjnych opartych na kreowaniu własnego wizerunku jako osoby silnej, dynamicznej, bezkompromisowej, walczącej wszelkimi środkami ze złem, które uosabia wróg polityczny;

- instynktowne zachowania przejawiające się w zrytualizowanych formach walki o przewodnictwo w stadzie (typowe dla świata zwierząt). (Kamińska-Szmaj, 2007, s. 53-54) 


\title{
3. Dyrektywne akty mowy jako narzędzia agresji językowej
}

Nazwane już zjawiska mogą z powodzeniem być zwerbalizowane również za pomocą dyrektywnych aktów mowy, które ex definitione mają zaspokajać potrzeby, żądania, pragnienia, braki i oczekiwania nadawcy (zob. Searle, 1999, s. 234). Filozof języka John R. Searle pisze: „Prosić, żądać, rozkazywać, błagać, zarządzać, upraszać, kazać (by A było zrobione) uchodzi za wyraz chcenia czy pragnienia (by A było zrobione)" (Searle, 1987, s. 87).

Przy uwzględnieniu czynników pragma- i socjolingwistycznych dyrektywne akty mowy są rezultatem współwystępowania następujących elementów:

\author{
Interlokutorzy: \\ Nadawca/-y; odbiorca/-y
}

Przyczyna komunikacji pomiędzy nimi:

Chęć/zamiar/potrzeba/konieczność nadawcy do zobligowania/zmuszenia/wpłynięcia na odbiorcę w celu pobudzenia go do działania według woli/potrzeby/obowiązku/chęci nadawcy, wyartykułowana w przedmiocie dyrektywnego aktu mowy.

Narzędzie do przekazania przedmiotu dyrektywnego aktu mowy:

Kod językowy, w ramach którego w trakcie konkretnego aktu komunikacji językowej zrealizowany zostanie określony dyrektywny akt mowy.

Kompetencja komunikacyjna interlokutorów:

Poziom znajomości języka - jego struktur semantycznych i syntaktycznych, zasad etykiety językowej i norm kulturalnego zachowania się obowiązujących w danej społeczności.

Czynniki wewnętrzne:

Stan psychiczny rozmówców, poziom emocji występujących między nimi, stopień poufałości, płeć, wiek.

Czynniki zewnętrzne:

a) niezależne od woli interlokutorów: uwarunkowania natury historycznej, kulturowej, socjalnej, społecznej;

b) zależne lub częściowo zależne od woli rozmówców: okoliczności, w jakich przebiega komunikacja, uwzględniające przeszkody w postaci różnego rodzaju zakłóceń (hałas, obecność innych osób, jednoczesne wypełnianie innych czynności itd.). (Pytel-Pandey, 2019, s. 40)

Nadawca często nie uwzględnia oceny i stosunku odbiorcy co do sposobu ich wypowiadania i metod realizacji. Szczególnie dzieje się tak, jeżeli zostaną one wyartykułowane z użyciem komunikacyjnych wykładników agresji, do których według Stanisława Gajdy należą:

— podniesiony głos (aż do krzyku) lub rzadziej ściszony;

- przyspieszone tempo mowy lub rzadziej zwolnione;

— ostry (jadowity, rozkazujący itd.) ton;

— ironia (drwina, szyderstwo) połączone ze śmiechem;

— przekrzykiwanie oraz wpadanie w cudzą mowę, przerywanie sobie w pół słowa;

— milczenie (agresywne) i niedomówienie; 
— zniekształcanie słów (także w druku);

— przedrzeźnianie i aluzje fonetyczne. (Gajda, 2002, s. 64)

Możliwości wyrażania agresji językowej związane są ze środkami fonetycznymi, morfologicznymi, leksykalnymi, stylistycznymi i syntaktycznymi, których funkcja polega na negatywnej emocjonalizacji wypowiedzi. W związku z tym połączenie nazwanych już sposobów komunikacji z odpowiednimi dyrektywnymi, ekspresywnymi i deklaratywnymi aktami mowy daje pożądany przez nadawcę efekt — agresja słowna może osiągnąć niezwykle wysoki poziom. Do ulubionych narzędzi agresorów spośród dyrektywnych aktów mowy bez wątpienia należą: żądania, szantaże, przymuszenia, pobudzenia/zachęty do czegoś, rady, ostrzeżenia — bardzo często każdy z tych aktów występuje w połączeniu z groźbami (zob. Grochowski, 1989, s. 33-44). Bożena Taras podkreśla, że są środki agresji językowej, które ze względu na ich mocny, a ja dodałabym jeszcze — nierzadko wulgarny, nasycony przemocą, charakter należy taktować jako społecznie szkodliwe (Taras, 2013, s. 55). Stają się one podstawowym składnikiem mowy nienawiści, która ma destrukcyjną siłę oddziaływania na odbiorcę i może być bardzo niebezpiecznym narzędziem w rękach nadawcy.

\section{Przykłady wypowiedzi agresywnych, w których zostały użyte dyrektywne akty mowy (żądania)}

Najczęściej pojawiającym się dyrektywnym aktem mowy o wyraźnie agresywnym wydźwięku są żądania. Ich nadawca jest przekonany, zgodnie z własną oceną, że ma prawo wymagać od odbiorcy, aby ten wypełnił jego oczekiwania, i przy użyciu różnych środków chce go do tego zobligować. Podane w dalszej części tego podrozdziału przykłady żądań zaistniały w przestrzeni publicznej w drugim dziesięcioleciu XXI wieku. Były to wypowiedzi polityków skierowane do przedstawicieli partii reprezentujących odmienne przekonania, dziennikarzy stawiających niewygodne (w mniemaniu współrozmówcy) pytania i innych osób powszechnie znanych. Agresja została w nich wyartykułowana za pomocą środków językowo-stylistycznych, których zadaniem było: deprecjonować, ośmieszać, ukazywać w jak najgorszym świetle adresata. Ważnym czynnikiem przy próbie oceny podanych wypowiedzi jest fakt, że padały one z ust ludzi szanowanych i cenionych w różnych grupach społecznych.

Dalej prezentuję przykłady zawierające słownictwo prymarnie i wtórnie negatywnie wartościujące:

1.

a) Żądania zawierające słownictwo prymarnie negatywnie wartościujące nazwy określające ludzi pozbawionych wartości moralnych, intelektualnych, kulturalnych oraz z pogardą oceniające ich wygląd fizyczny: 
—Zamknij mordę, chamie (takimi słowami prezes Prawa i Sprawiedliwości Jarosław Kaczyński zwrócił się do przemawiającego posła Platformy Obywatelskiej Sławomira Nitrasa — www7);

— Siadaj kurduplu! (Armand Ryfiński do Jarosława Kaczyńskiego podczas obrad Sejmu - www15);

- Aferzyści, zlodzieje i idioci, czyli wszystkich won! (www2).

b) Żądania zawierające przymiotniki i rzeczowniki pejoratywnie wartościujące adresata:

- Spieprzaj, klamliwa babo obrzydliwa (osoby, które otoczyły Magdalenę Ogórek pod budynkiem TVP — www4);

- Padnij przed Panem Profesorem na kolana, durna babo! Nie dorastasz temu człowiekowi do pięt pod względem wiedzy prawniczej i inteligencji (Maria Nurowska o Małgorzacie Wassermann - www6);

- Mam apel właściwie do tej części sali lewej, żeby opanowała chamstwo lewackie swojej przedstawicielki, która bez obrażania kogokolwiek nie potrafi po prostu mordy otworzyć swojej (żądanie/apel/prośba; posłanka Krystyna Pawłowicz, posiedzenie komisji sejmowej — www11);

- ZLIKWIDOWAĆ TRYBUNAE KONSTYTUCYJNY - LEWACKI KAGANIEC przeciw odrodzeniu sie Wolnej Polski (zachowana pisownia oryginalna, transparent z obchodów Dnia Konstytucji 3 Maja w Poznaniu w 2017 roku www20).

c) Żądania zawierające czasowniki nazywające działania niegodne, naganne, potępiane przez otoczenie:

- Panie premierze, niech pan nie klamie! W dalszym ciagu mamy $900 \mathrm{zt}$ na życie, a nie 3 tysiace. Prosze przestać klamać (Jakub Hartwich do premiera Mateusza Morawieckiego w korytarzu sejmowym — www12);

- Tusku, nie oszukuj Polaków! (Ziobryści i PiS do Donalda Tuska www17);

- Bardzo proszę, aby PIS przestato szczuć Polaków na naszego największego partnera handlowego (Radosław Sikorski - www13);

- Nie szczujcie Polaków przeciwko sobie (www19);

- Przestańcie manipulować opinia publiczna i ukazywać nauczycieli w złym świetle, weźcie odpowiedzialność za ich strajk (www1).

d) Żądania wyrażone wykrzyknikiem o charakterze apelatywnym, na przykład: won, precz:

—Won stąd! (Jarosław Kaczyński do Kamili Gasiuk-Pihowicz — www7);

- Won za Don czerwona zarazo! (www16);

- Won stad, won do Pis-u! (Stefan Niesiołowski do dziennikarki Ewy Stankiewicz - www18);

- Precz z Kaczorem-Dyktatorem! (demonstracja na Rynku Głównym w Krakowie - www8). 
2. Żądania zawierające słownictwo wtórnie wartościujące - użycie słownictwa dotyczącego świata zwierząt w odniesieniu do ludzi:

— Stul pysk! Zamknij ryj! (www9);

- Wiem, że boicie się prawdy, ale nie wycierajcie swoich mord zdradzieckich nazwiskiem mojego śp. brata (Jarosław Kaczyński w Sejmie — www14);

- Lapy precz od Polski (www10);

- Obywatelu, morda w kubet (www21).

W podanych przykładach widać, że słownictwo prymarnie i wtórnie negatywnie wartościujące występuje również łącznie w jednej wypowiedzi.

\section{Podsumowanie}

Zademonstrowane przykłady dyrektywnych aktów mowy — żądań, które pojawiły się w wypowiedziach o charakterze agresywnym, mogą świadczyć o tym, że:

- są one odpowiednimi środkami do budowania wypowiedzi o charakterze agresywnym, co może prowokować do opinii, że agresja jest określoną szeroko rozumianą formą buntu opartą na żądaniach wobec innych, siebie, otaczającego świata;

— agresorzy chętnie po nie sięgają, chcąc osiągnąc swój cel komunikacyjny;

— obserwujemy duże zubożenie w przestrzeganiu reguł dobrego zachowania wśród elit politycznych;

- wypowiedzi osób pełniących różne funkcje partyjne, państwowe, społeczne nacechowane są często brakiem szacunku i kultury wobec współrozmówców, szczególnie mających odmienne poglądy;

— w społeczeństwie polskim można doszukać się wielu powodów powstawania agresywnych wypowiedzi, które zmieniają się pod wpływem bieżących wydarzeń - ich źródła powinny być przedmiotem kolejnych badań naukowych (w niniejszym tekście zostały one jedynie zasygnalizowane).

Prowadzenie badań nad współczesną komunikacją pomoże poznać społeczeństwo i jego sposób odbioru rzeczywistości, stosunek do drugiego człowieka i zmieniające się reguły wchodzenia w kontakt językowy pomiędzy jego członkami, a w konsekwencji również zapobiec powstawaniu wielu nieporozumień.

\section{Bibliografia}

\section{Literatura}

Dąbrowska, A., Nowakowska, A. (red.). (2005). Język a Kultura, t. 17. Życzliwość i agresja w języku $i$ kulturze. Wrocław: Wydawnictwo Uniwersytetu Wrocławskiego.

Gajda, S. (2002). Agresja językowa w stosunkach międzyludzkich. W: W. Gruszczyński (red.), Język narzędziem myślenia i działania (s. 59-66). Warszawa: Dom Wydawniczy „Elipsa”. 
Grochowski, M. (1989). O pojęciu groźby. Polonica, 14, s. 33-44.

Grybosiowa, A. (2001). Kilka refleksji na temat zasad (maksym) konwersacyjnych H.P. Grice. Poradnik Językowy, 7, s. 7-11.

Kamińska-Szmaj, I. (2007). Agresja językowa w życiu publicznym. Leksykon inwektyw politycznych 1918-2000. Wrocław: Wydawnictwo Uniwersytetu Wrocławskiego.

Kondzioła-Pich, K. (2018). Charakterystyka dyrektywnych aktów mowy występujących w hejcie internetowym. Socjolingwistyka, 32, s. 163-174.

Laskowska, E. (2005). Przejawy życzliwości i agresji w wypowiedziach publicznych (na przykładzie języka Rady Miejskiej Bydgoszczy). W: A. Dąbrowska, A. Nowakowska (red.), Język a Kultura, t. 17. Życzliwość i agresja w języku i kulturze (s. 81-89). Wrocław: Wydawnictwo Uniwersytetu Wrocławskiego.

Lewiński, P. (2005). O wyrazach ogólnie obelżywych. W: A. Dąbrowska, A. Nowakowska (red.), Język a Kultura, t. 17. Życzliwość i agresja w języku i kulturze (s. 101-111). Wrocław: Wydawnictwo Uniwersytetu Wrocławskiego.

Majewska, M. (2005). O implikowaniu i presupozycyjnym przemycaniu treści deprecjonujących odbiorcę. W: A. Dąbrowska, A. Nowakowska (red.), Język a Kultura, t. 17. Życzliwość i agresja w języku i kulturze (s. 155-161). Wrocław: Wydawnictwo Uniwersytetu Wrocławskiego.

Marcjanik, M. (1990). Normy regulujące językowe zachowania grzecznościowe. Przegląd Humanistyczny, 34, nr 7, s. 77-82.

Marcjanik, M. (1993). Etykieta językowa. W: J. Bartmiński (red.), Encyklopedia kultury polskiej XX wieku, t. 2 (s. 271-281). Wrocław: Wydawnictwo Wiedza o Kulturze.

Mazur, J., Rzeszutko, M. (2000). Słownictwo „NIE” jako przykład agresji i wulgaryzacji języka we współczesnej polszczyźnie. W: J. Mazur (red.), Słownictwo współczesnej polszczyzny w okresie przemian (s. 149-160). Lublin: Wydawnictwo Uniwersytetu Marii Curie-Skłodowskiej.

Peisert, M. (2004). Formy i funkcje agresji werbalnej. Próba typologii. Wrocław: Wydawnictwo Uniwersytetu Wrocławskiego.

Pietrzak, H. (2000). Agresja - konflikt - społeczeństwo. Tyczyn: Wyższa Szkoła Społeczno-Gospodarcza w Tyczynie.

Pytel-Pandey, D. (2016). Akty agresji językowej na przykładach z języka polskiego i rosyjskiego. Slavica Wratislaviensia, 162, s. 103-110.

Pytel-Pandey, D. (2018). Taktyki agresji językowej na przykładzie języków rosyjskiego i polskiego. W: K. Kondzioła-Pich, A. Pięcińska (red.), Stowa i ludzie - ludzie i słowa. Językowe aspekty komunikacji międzyludzkiej (s. 137-147). Szczecin: Volumina.pl Daniel Krzanowski.

Pytel-Pandey, D. (2019). Dyrektywne akty mowy w języku rosyjskim i niemieckim w świetle wspótczesnej komunikacji werbalnej. Wrocław: Wydawnictwo Uniwersytetu Wrocławskiego.

Searle, J. R. (1987). Czynności mowy. Rozważania z filozofii języka (Speech Acts. An Essay in the Philosophy of Language, 1977), przeł B. Chwedeńczuk. Warszawa: Instytut Wydawniczy Pax.

Searle, J. R. (1999). Umyst, język, spoleczeństwo. Filozofia i rzeczywistość (Mind. Language and Society. Philosophy in the Real Word, 1998), przeł. D. Cieśla. Warszawa: W.A.B.-CiS.

Smereka, T. (2005). Agresja i życzliwość w kontekście zachowań komunikacyjnych. W: A. Dąbrowska, A. Nowakowska (red.), Język a Kultura, t. 17. Życzliwość i agresja w języku i kulturze (s. 69-89). Wrocław: Wydawnictwo Uniwersytetu Wrocławskiego.

Taras, B. (2013). Agresja. Studium semantyczno-pragmatyczne. Rzeszów: Wydawnictwo Uniwersytetu Rzeszowskiego.

Witorska, A. (2005). Co to jest agresja? Studium semantyczne. W: A. Dąbrowska, A. Nowakowska (red.), Język a Kultura, t. 17. Życzliwość i agresja w języku i kulturze. (s. 145-154). Wrocław: Wydawnictwo Uniwersytetu Wrocławskiego. 


\section{Źródła internetowe}

www1: https://gorzow.wyborcza.pl/gorzow/7,36844,24674332,strajk-nauczycieli-przestanciemanipulowac-opinia-publiczna.html (dostęp: 7.01.2020).

www2: http://jow.pl/aferzysci-zlodzieje-idioci-won/ (dostęp: 19.10.2019).

www3: https://pl.wikipedia.org/wiki/Agresja_j\%C4\%99zykowa (dostęp: 10.10.2019).

www4: https://www.polskieradio24.pl/5/3/Artykul/2257094,Rekoczyny-i-wyzwiska-Ataki-nadziennikarzy-TVP-trwaja-od-3-lat (dostęp: 23.02.2020).

www5: https://sjp.pwn.pl/szukaj/agresja\%20.html (dostęp: 10.10.2019).

www6: https://tysol.pl/a21982-Nurowska-obraza-Malgorzate-Wassermann-Padnij-przed-PanemProfesorem-na-kolana-durna-babo- (dostęp: 16.01.2020).

www7: https://tvn24.pl/wideo/z-anteny/won-stad-zamknij-morde-chamie-kaczynskiemu-puscilynerwy,1643667.html?playlist id=31421 (dostęp: 21.02.2020).

www8: https://wiadomosci.gazeta.pl/wiadomosci/7,114884,21116103,precz-z-kaczoremdyktatorem-w-krakowie-obalono-pomnik-prezesa.html (dostęp: 9.03.2020).

www9: https://wiadomosci.dziennik.pl/polityka/artykuly/478252, awantura-w-sejmie-o-poslankepawlowicz-kaczynski-uslyszal-siadaj-kurduplu.html (dostęp: 15.10.2019).

www10: https://www.fronda.pl/a/krs-odpowiada-na-pytanie-unijnej-instytucji,141465.html (dostęp: 10.03.2020).

www 11: http://www.gazeta.tv/Wideo/10,130252,23251113,nie-potrafi-otworzyc-mordy-bezobrazania-krystyna-pawlowicz.html\#fixedUrl (dostęp: 1.03.2020).

www12: https://www.newsweek.pl/polska/polityka/jakub-hartwich-do-mateusza-morawieckiegoniech-pan-nie-klamie/vtcyyqd (dostęp: 8.01.2020).

www13: https://www.newsweek.pl/polska/sikorski-do-pis-nie-szczujcie-polakow-przeciw-niemcom/zv289bp (dostęp: 16.02.2020).

www14: https://www.newsweek.pl/swiat/polityka/kaczynski-w-sejmie-o-zdradzieckich-mordachi-kanaliach/13z6c75 (dostęp: 9.03.2020).

www 15: https://www.se.pl/wiadomosci/polityka/warknal-na-kaczynskiego-siadaj-kurduplu-arm and-ryfinski-zachowal-sie-beznadziejnie-aa-cnKa-gs5x-nBRo.html (dostęp: 8.03.2020).

www 16: https://www.tysol.pl/a33466--Won-za-Don-czerwona-zarazo\%21-Tarczynski-ostroodpowiada-Rosatiemu (dostęp: 10.02.2020).

www17: https://www.wprost.pl/kraj/304190/ziobrysci-i-pis-tusku-nie-oszukuj-polakow.html (dostęp: 10.03.2020).

www18: https://www.wprost.pl/kraj/321898/niesiolowski-atakuje-pod-sejmem-won-do-pis-u.html (dostęp: 1.03.2020).

www19: https://wyborcza.pl/7,95891,21464784,przestancie-dzielic-i-obrazac-pamietajcie-wszy scy-jestesmy.html (dostęp: 7.03.2020).

www20: https://wyborcza.pl/politykaekstra/1,132907,20092135,prawo-ustawowe-omijaniekonstytucji.html (dostęp: 28.02.2020).

www21: https://wyborcza.pl/7,75968,24923731,obywatelu-morda-w-kubel.html (dostęp: 19.12.2020). 